\title{
COMPARATIVE COMPETITIVENESS INDICATORS, WHICH RANKING FOR THE ALGERIAN TOURISM?
}

\author{
Ratiba BAOUALI* \\ USTHB (Houari Boumediene Sciences and Technology University), Department of Geography and \\ Territorial Planning, BP 32, El Alia, Bab Ezzouar, 16111, Algiers, Algeria, e-mail: baoualir@hotmail.fr

\section{Amel BAZIZ} \\ USTHB (Houari Boumediene Sciences and Technology University), Department of Geography and \\ Territorial Planning, BP 32, El Alia, Bab Ezzouar, 16111, Algiers, Algeria, e-mail: Bazizusthb@yahoo.fr
}

\begin{abstract}
Ali HADJIEDJ
USTHB (Houari Boumediene Sciences and Technology University), Department of Geography and Territorial Planning, BP 32, El Alia, Bab Ezzouar, 16111, Algiers, Algeria, e-mail: Alilreau @hotmail.fr
\end{abstract}

Citation: Baouali, R., Baziz, A., \& Hadjiedj, A. (2019). COMPARATIVE COMPETITIVENESS INDICATORS, WHICH RANKING FOR THE ALGERIAN TOURISM? GeoJournal of Tourism and Geosites, 24(1), 133-145. https://doi.org/10.30892/gtg.24111-348

\begin{abstract}
This article presents an analysis of the different methods and summary indicators published by international organizations (World Economic Forum, United Nations, etc.) to rank the countries globally in terms of the attractiveness and competitiveness of tourism. The study focuses on the case of Algeria, a country with a rich and diversified tourist potential that should definitely be a destination on the international or regional scale, just like its neighbors in the Maghreb (Morocco and Tunisia). Recent figures on Algeria's world rankings in terms of competitiveness described a reality far from this hypothesis. The 2017 Travel \& Tourism Competitiveness Report ranked Algeria in the $118^{\text {th }}$ out of 136 countries. Same wise the World Economic Forum (WEF) in its 2018 edition, put Algeria in the least attractive countries ranked 92nd out of 140. As generally known the territorial attractiveness is at the core concept of the competitiveness of the touristic destinations. However, this does not apply in the case of Algeria, as developed further in this article the country is attractive but not competitive.An American researcher Allain Lew (Lew, 1987) established a framework for the tourism attraction. Lew proposed a definition to attractiveness as: "The basic element on which tourism is developed" (Lew, 1987, p. 554) if we consider the definition of Lew, the Algerian territory is extremely attractive, therefore contradictory to the above mentioned rankings. This definition brings out a substantial problem, related to the measurement of attractiveness. On what basis can we say that one territory is attractive or that it is more attractive than another? What indicators are used to classify the territories according to their degree of attractiveness? To answer this problem, we have proceeded to a comparative approach of different rankings and their respective effectiveness. We also proceeded to a quantitative approach which consists in calculating two indicators
\end{abstract}

\footnotetext{
* Corresponding author
} 
of tourist attractiveness across the Algerian territory for the period 2008-2017.

(The index of territorial attractiveness and the average duration of stays).

Key words: Territorial Attractiveness, Competitiveness of Destinations, Tourist Attractions

\section{INTRODUCTION}

In this introduction we will present difference scientific views that shaped the definition, calculation and indicators of touristic attractiveness and competitiveness.

Gollain \& Lepage have privileged the endogenous attractiveness approach that consisted on identifying the reasons behind the territorial attractiveness (Gollain \& Lepage, 2015). These analyses will help identifying and analyzing the factors of competitiveness that create comparative advantages and will have impact on the attractiveness (presence and quality of infrastructures, human capital, services provided, etc., measure the impact of the external environment (variation of the currency rate, regulation, rate of economic growth, etc.) on attractiveness performance.

This concept has also been studied by other researchers from different fields (economics, marketing, geography, tourism, sociology, etc.) (Ritchie \& Zins, 1978; Smith 1980, Lew, 1987; Smith, 1987; Leiper, 1990; Nolan \& Nolan, 1992; Kim, 1998; Deng et al., 2002; Gallarza et al., 2002; Enright \& Newton, 2004; van der Ark \& Richards, 2006; Escadafal, 2007; Khadaroo \& Seetanah, 2008; Cracolici \& Nijkamp, 2008; Wang \& Hsu, 2010; Kusen, 2010; Kim, 2010). Essentially, the concept of attractiveness of the territory is associated to attributes that compose the territory and make it attractive, whether for living, business, for visit, etc. The attractiveness of the territory can therefore be associated with the attractiveness of its composition and the retention of its population. This concept is not related exclusively to geography, but the territory makes it indivisible. From a tourist point of view, the attributes that constitute the territory are a set of tangible and intangible attractions that will positively or negatively influence tourists. To be attractive, a territory must be able to provide infrastructure and services that will provide travelers with a remarkable, unique and intense experience. Tourist infrastructure plays a major role in the development of a touristic product.

The question of tourism attractiveness can therefore be part of a general reflection on the development of attractiveness through the valorization of "Territorial" resources (Lew, 1987). These resources can be generic or specific, active or dormant. The valorization processes assume that the tourism business engage in strategies of differentiation by the costs or by the quality of the offer (excluding cost) that consider the specificity of the offer and its components.

The comparison of the concepts of attractiveness and competitiveness between the economy of tourism and the Geography of tourism reveals the ambiguity of these notions because it is common to use the terms competitiveness and attractiveness as synonyms (Lepage \& Gollain, 2015).This observation leads us to clarify these terms and to distinguish several underlying concepts, such as level of amenity or source of amenity. In addition, the reconciliation of these two literatures leads to the idea that attractiveness is likely to influence the location of tourists on two different scales. From the work of (Courlet \& Pecqueur, 2013; Devereux \& Griffith 1998; Hatem, 2004). Among other things, the attractiveness of a territory can be defined as its capacity over a given period to:

- Attract and retain various economic activities and mobile factors of production 
(companies, professional events, people of talents, entrepreneurs, capital, etc. which are sometimes external to the region.

- Promote the creation of wealth and the growth of endogenous enterprises, centers of excellence and economic sectors.

Most of the work on this topic has so far touched on it in different ways, but no theoretical model has succeeded, to our knowledge, in establishing the empirical links between attractiveness and competitiveness.

\section{MATERIALS AND METHODS}

The methodology used in this article will make use of a multi-step approach:

- Documentary research to clarify our theoretical argument: they will focus on the examination of articles and books on the tourist economy, territorial attractiveness, and competitiveness of destinations;

- A qualitative analysis that consists of evaluating the reliability of global competitiveness indicators obtained from international institutions such as: the World Tourism Organization, the World Economic Forum and ... etc;

- A quantitative analysis that consists of calculating two tourist attractiveness indices through the Algerian territory for the period 2008-2017.

$\checkmark$ The index of territorial attractiveness that results from the ratio between the number of tourists returning to the Algerian territory and the number of residents leaving the territory.

$\checkmark \quad$ The average length of stay which is a direct and objective means of assessing the success of tourism, the difference between the data of two successive years being a transparent and simple way of demonstrating that there has been growth or contraction. But overnight stays better reflect the impact of tourism on the economy than other indicators such as the number of visitor arrivals.

To simplify the reading of the results of calculation, we realized a hotel night card by province and a map of Flow tourist towards Algeria by continents of Provenance.

\section{RESULTS DISCUSSIONS \\ THE ATTRIBUTES THAT DETERMINE THE ATTRACTIVENESS OF THE ALGERIAN TERRITORY}

In his research (Galarneau, 2015) clarified the attractiveness of a territory as a relatively complex concept that relates to the motivations of individuals to travel, the specificities of his decision-making and the influence of socio-economic and cultural variables. Therefore, the attractiveness of a territory is not acquired since it must be constantly renewed to meet the new realities. The attractiveness of the territory is therefore the potential of a region to attract tourists according to the quantity and diversity of the natural and human attributes that compose it while adapting to the market demand. A territory that wants to develop its lures in order to make its product more attractive must be able to diversify its offer of services and to rely on natural places, tourist infrastructures, a diversity of attractions including historic and cultural places, entertainments, in addition to providing transportation services and introducing welcoming people with a culture different from tourist's culture. The territory is therefore a product that can be modeled according to the segments of the targeted markets.

To measure the impact of the lures of the regions on the attractiveness of the territory, our work will cover the study of the touristic position of Algeria, the accessibility of the territory and the various attractions present in certain touristic regions.

Table 1 presents a summary, by category, of all the attributes making up the attractiveness according to the research conducted by the authors consulted in the context 
of this article. The compilation of the attributes shows that some of them are more important than others such as: the presence of natural places, the infrastructures of reception, tourist attractions, the historic places, the accessibility and transport. None of the authors associate attractiveness to a single attribute. On average, each of the authors referred to eight attributes to determine the attractiveness of the territory. Based on this table, Algerian territory has all the advantages that will allow us to qualify it as attractive.

Table 1. Attributes of the attractiveness of the Algerian territory

(Data source: Tourist Priority Projects, SDAT 2025, book 1 Ministry of Tourism of Algeria 2008, p.6)

\begin{tabular}{|c|c|c|}
\hline & Attributes & State in Algeria \\
\hline $\begin{array}{l}\text { Natural } \\
\text { heritage }\end{array}$ & $\begin{array}{l}\text { Climate and } \\
\text { landscape }\end{array}$ & $\begin{array}{l}\text { The climate is typically Mediterranean with hot and dry } \\
\text { summers but with mild and rainy winters. } \\
2.38 \text { million } \mathrm{Km}^{2} \text { (10 countries the largest in the world) has } \\
\text { many facets ranging from the coastline, the Atlas Mountains, } \\
\text { the Highlands, the Sahara*. }\end{array}$ \\
\hline \multirow[b]{2}{*}{ Logistics } & $\begin{array}{l}\text { Home } \\
\text { infrastructure }\end{array}$ & $\begin{array}{l}1185 \text { hotels with a capacity of } 112264 \text { (2017 tourism and craft } \\
\text { dashboard, p.12). }\end{array}$ \\
\hline & $\begin{array}{l}\text { Accessibility } \\
\text { and transport }\end{array}$ & $\begin{array}{l}\text { The Algerian road network remains one of the densest on the } \\
\text { African continent, its length is } 133,741 \mathrm{~km} \text {, It is dense in the } \\
\text { northern fringe of the country, quite loose on the highlands } \\
\text { and is reduced to a few axes in the south the feral network } 4 \\
500 \mathrm{Km} 35 \text { airports } 13 \text { main ports. }\end{array}$ \\
\hline \multirow{3}{*}{$\begin{array}{l}\text { Tourist } \\
\text { product }\end{array}$} & $\begin{array}{l}\text { Cultural and } \\
\text { historical place }\end{array}$ & $\begin{array}{l}\text { O7 World Heritage Sites } 437 \text { Historic } \\
\text { Sites(https://whc.unesco.org/fr/etatsparties/dz) }\end{array}$ \\
\hline & Event & $\begin{array}{l}29 \text { international festivals, national 33, local } 100 \text { (Statistics } 2017 \\
\text { Ministry of Culture Yearbook, p.167). }\end{array}$ \\
\hline & $\begin{array}{l}\text { Shopping } \\
\text { centers }\end{array}$ & $\begin{array}{l}\text { O5 Hypermarket with international standards, Supermarket } \\
\text { 1739, (National Trade Registry Center). }\end{array}$ \\
\hline \multirow{2}{*}{$\begin{array}{l}\text { Economic } \\
\text { social } \\
\text { factors }\end{array}$} & Security & $\begin{array}{l}\text { Ranked } 54 / 138 \text { in security (Global Terrorism Index 2018, p.9.) } \\
\text { Algeria no longer in the top } 10 \text { of high-risk countries }\end{array}$ \\
\hline & Price & Ranked 4/136 in TTCR 2017 \\
\hline
\end{tabular}

\section{TERRITORIAL ATTRACTIVENESS A CONCEPT OR A MEASURE?}

According to international litérature, only one work referred to the calculation of the territorial attractiveness (Giotart et al., 2012).

The authors of this work have calculated the coefficient of territorial attractiveness CAT as the ratio between incoming and outgoing flows, the CAT can be used as a macroindicator among the various methods of evaluation of tourist attractiveness of a territory.

According to (Hatem, 2004) economic vision, five main categories of approaches include the concept of attractiveness, the image-based approach, the decision-making approach, the macro approach by global indicators, the "meso" approach through the differentiated offer and the "micro" approach.

\section{CALCULATION OF THE COEFFICIENT OF TERRITORIAL ATTRACTIVENESS (CTA)}

The calculation of the CTA according to Giotart, J. Balfet, M., Leroux, E. (Giotart et al., 2012) is often a convenient indicator to follow the evolution of the attractiveness of a touristic place, it is the calculation of the ratio between incoming and outgoing flows, and the CAT can be used as a macro-indicator among the various methods of evaluating the attractive power of a territory. 
According to the Table 2 and graph in Figure 1, for the period 2008-2013 The CTA has known a constant evolution accompanied by a significant evolution of the number of inflows while the period 2013 - 2017 is marked by a remarkable reduction of the CTA and an increase of the flows outbound with stability of inflows. Its figures denote the unreliability of this coefficient measured the attractiveness of a territory.

Table 2. Evolution of the coefficient of attractivenessof the Algerian territory

(Data source: Report on the Algerian tourism indicators 1999-2017 Ministry of Tourism, 2017, p.4 )

\begin{tabular}{|l|c|c|c|c|c|c|c|c|c|c|}
\hline Year & 2008 & 2009 & 2010 & 2011 & 2012 & 2013 & 2014 & 2015 & 2106 & 2017 \\
\hline Incoming flows $\left(10^{2}\right)$ & 1771 & 1911 & 1792 & 2123 & 2634 & 2732 & 2301 & 1709 & 2039 & 2450 \\
\hline Outflows $\left(10^{2}\right)$ & 1539 & 1676 & 1757 & 1714 & 1910 & 1910 & 2839 & 3638 & 4529 & 5058 \\
\hline CTA & 1.15 & 1.14 & 1.01 & 1.23 & 1.37 & 1.43 & 0.81 & 0,47 & 0,45 & 0,48 \\
\hline
\end{tabular}

${ }^{*}$ attractiveness coefficient $=$ incoming flows $/$ outflows

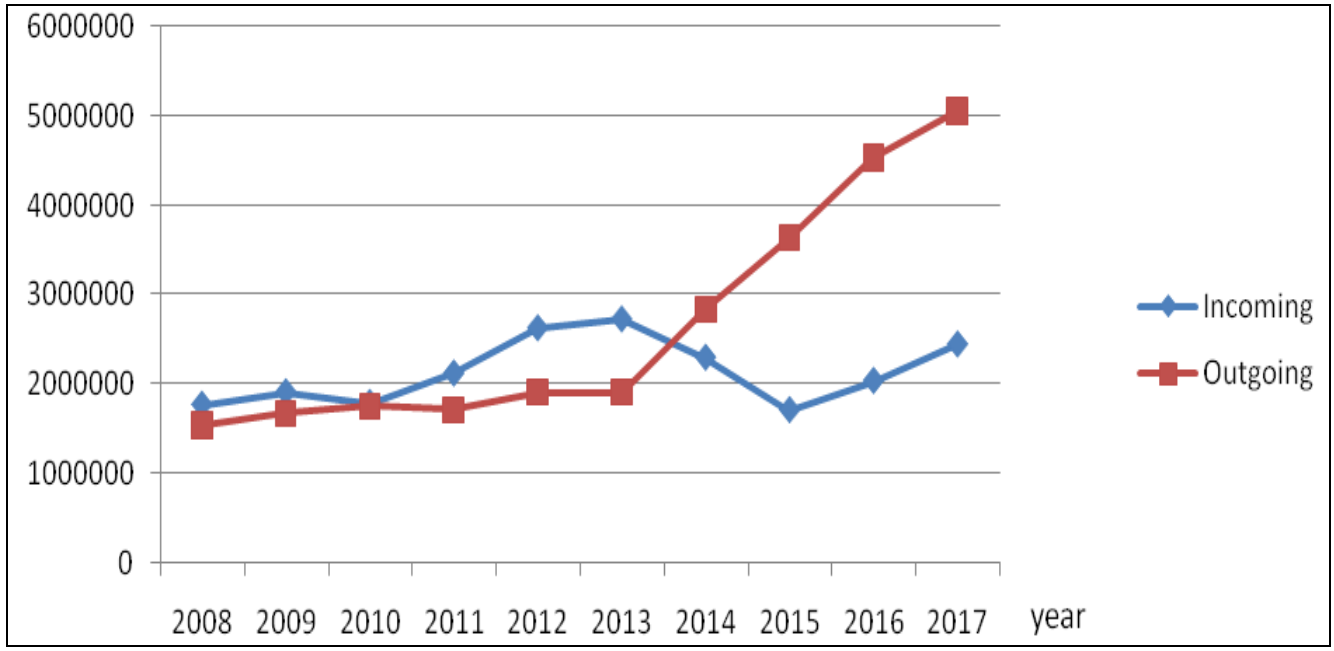

Figure.1. Evolution of the number of incoming and outgoing Algerian territory (Source: Report on the Algerian tourism indicators 1999-2017 Ministry of Tourism, 2017, p.4)

\section{MEASUREMENT OF ATTRACTIVENESS BY THE WORLD TOURISM ORGANIZATION (UNWTO)}

UNWTO is the United Nations Agency responsible for promoting tourism. This institution uses tourist flows, and especially the number of arrivals as a unit of measurement to determine the level of competitiveness of a destination. A drop in the tourist numbers for example is synonymous with a downward performance of activity, and consequently a decrease in the competitiveness of the destination in question. The attractiveness of the territory is a phenomenon that can be quantified since it can be measured according to the flows it generates (Viceriat et al., 2007; Khadaroo \& Seetanah, 2008). This attractiveness is also qualifiable since it can also be related to the perception of tourists (Kim, 1998; Gallarza et al., 2002; Wang \& Hsu, 2010; Kim, 2010). According to an (UNWTO Tourism Highlights, 2018 edition, p. 18). Algeria is the fourth most visited country in Africa with 2, 4 million foreign tourists welcomed in 2017, behind Tunisia, South Africa and Morocco. This result is quite contradictory to the results obtained by the indicators of synthesis applied on Algeria which is often ranked at the bottom of the table.

For even more accuracy, we have consulted (report on the Algerian tourism indicators 1999-2017 Ministry of Tourism, 2017, p.5) the observation was that of 2,4 
million tourists who visited Algeria in 2017, more than 742410 were Algerian expatriates returning to the country for the holidays represented $30 \%$ of foreigners. Just over 1470 243 tourists are foreigners. Thus, the number of flows adopted by the OMT to measure the attractiveness of the territory is to revalue. The map of flows by continent (Figure 3) and graph (Figure 2) shows that Africa is the leading emitter of international tourism followed by Europe, Asia the Middle East and America in last position. Therefore, the Algerian territory attracts the African population by excellence.

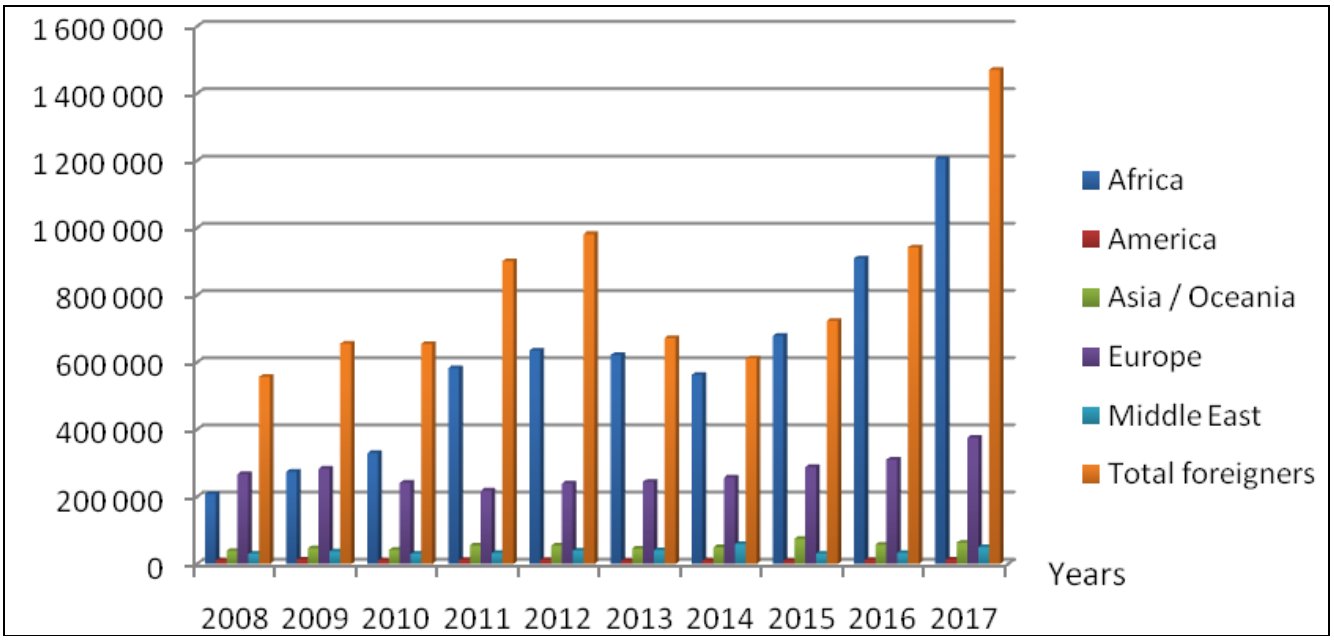

Figure 2. Evolution of border entries of foreign tourists (Source: 2017 tourism and craft dashboard, p.9)

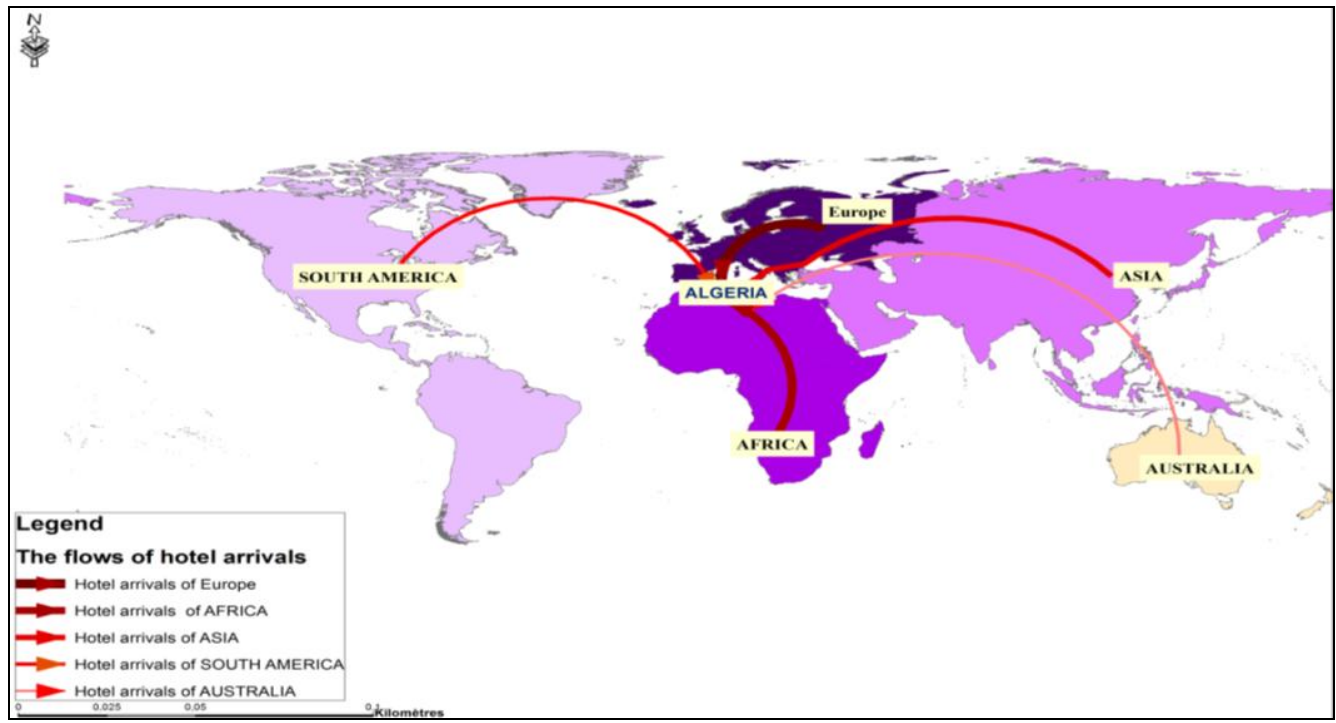

Figure 3. Distribution of hotel arrivals by continent (Source: 2017 tourism and craft dashboard, p.5)

\section{IS THE NUMBER OF HOTEL NIGHTS AN INDICATOR OF ATTRACTIVENESS?}

Tourism attractiveness can be measured by the number of hotel nights, this indicator reflects both the length of stay and the number of visitors. 
Figures 4 and 5 shows that the overnight stays in Algeria show a breakdown by province of the total number of overnight stays in all types of tourist accommodation in 2014. Tourism activity in Algeria was often concentrated in the coastal regions (mainly along the Mediterranean), in the desert gate.

Table 3. Evolutions of arrivals and hotels nights 2008-2017

(Data source: Report on the Algerian tourism indicators 1999-2017 Ministry of Tourism, 2017, p.9)

\begin{tabular}{|c|c|c|c|c|c|c|c|c|c|c|}
\hline Year & 2008 & 2009 & 2010 & 2011 & 2012 & 2013 & 2014 & 2015 & 2016 & 2017 \\
\hline Arrivals $\left(10^{2}\right)$ & 3167 & 3347 & 3527 & 3762 & 3959 & 4119 & 4173 & 4216 & 4320 & 4423 \\
\hline Nights $\left(10^{2}\right)$ & 5346 & 5645 & 5939 & 6472 & 6640 & 6921 & 7053 & 7146 & 7276 & 7406 \\
\hline $\mathrm{AL} \mathrm{S}^{*}$ & 1,69 & 1,68 & 1,68 & 1,72 & 1,72 & 1,68 & 1,69 & 1,69 & 1,68 & 1,67 \\
\hline
\end{tabular}

*AlS: Average Length of Stay (ALOS) = Number of Nights / Number of Arrivals

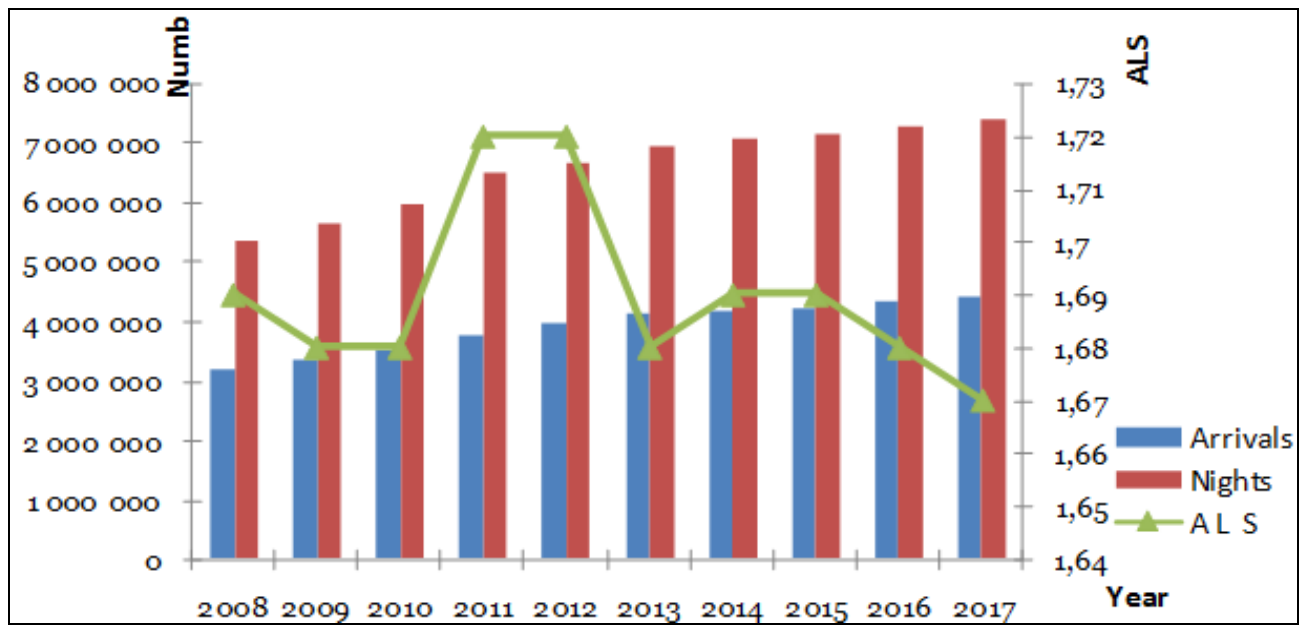

Figure 4. Evolution of arrivals and hotels nights 2008-2017

(Source: Report on the Algerian tourism indicators 1999-2017 Ministry of Tourism, 2017, p.9)

\section{BETWEEN ATTRACTIVENESS OF THE TERRITORY AND COMPETITIVENESS OF DESTINATIONS (POSITIONING OF ALGERIA BY THE INDICATORS OF SYNTHESIS)}

What can be noted from the empirical work on attractiveness is that in many cases the concept of attractiveness is equated with that of competitiveness the Organization for Economic Co-operation and Development (OECD) from which we extracted the following definition:"The competitiveness of tourism for a given destination corresponds to the capacity of the place to optimize its attractiveness for residents and non-residents, to offer the costumer quality, innovative and attractive tourist services (good value for money) and to gain market shares in the domestic and global market, while ensuring that the resources available to support tourism are used efficiently and sustainably (Dupeyras \& Maccallum, 2013, p. 15). Based on this definition, key indicators have been developed to address the challenges of competitiveness analysis in the tourism sector. However, the synthetic indexes of competitiveness such as those built by the World Economic Forum are not enough to measure the attractiveness. The theory assuming that Algeria was not attractive, lacked homogeneity, was not founded based on a clear theoretical vision of the determinants of attractiveness, and generated contradictory and volatile rankings. The following table lists the most popular indicators, and gives a historical background of development of these indicators. 


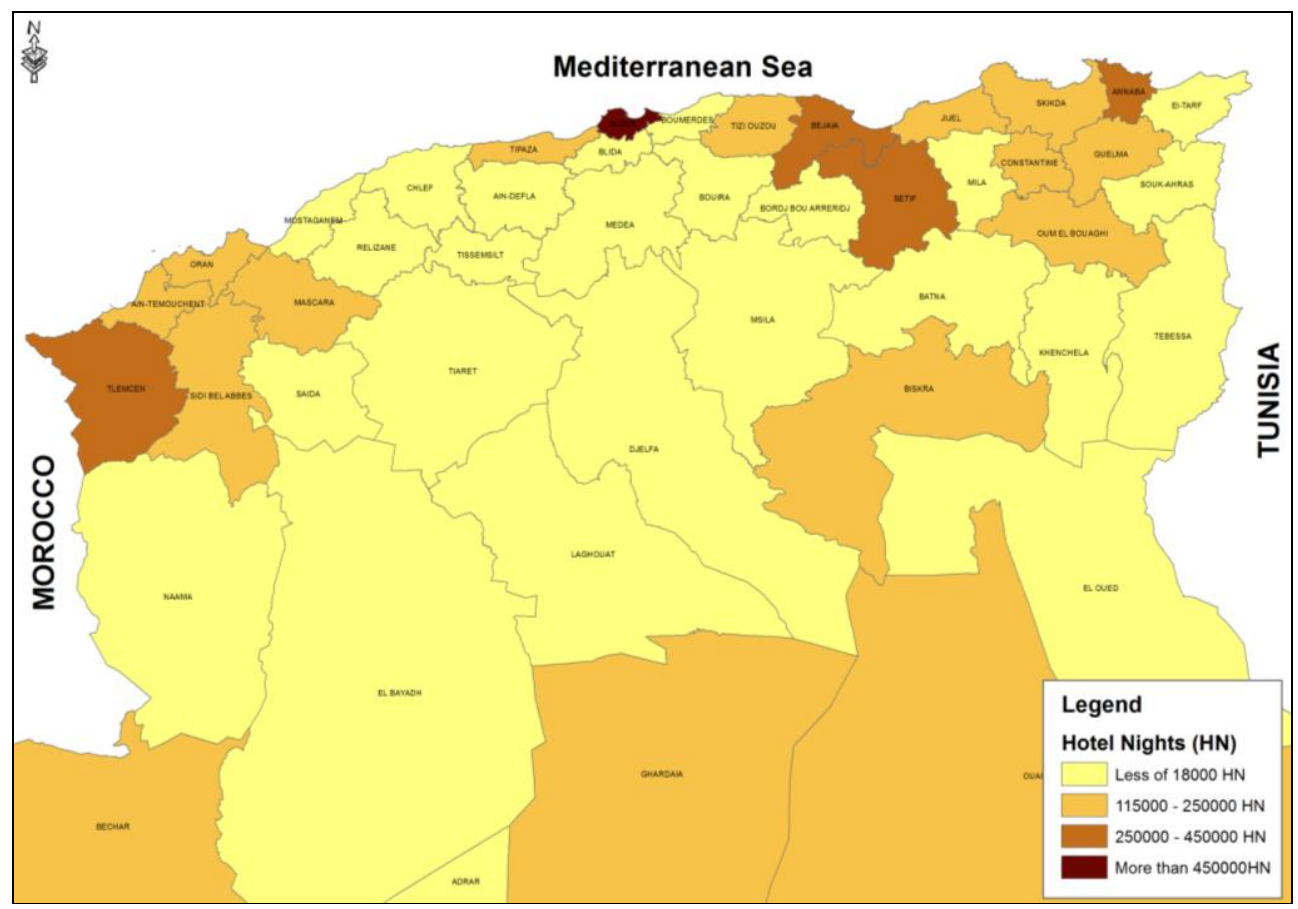

Figure 5. Breakdown of hotel stays by province (Source: 2017 tourism and craft dashboard, p.12)

Table 4. Measure of the Competitiveness of Algeria by the different indicators of synthesis (Data Source: The Global Competitiveness Report 2017, World Economic Forum, p.11; World Investment Report 2017; United Nations Conference On Trade And Development, p.44; World Travel \& Tourism competitiveness Report 2017, p.96; Human Development Index trends, 1990-2017, p.27)

\begin{tabular}{|c|c|c|c|}
\hline Publication & Year & World Ranking & Method \\
\hline \multirow{5}{*}{$\begin{array}{l}\text { World Economic } \\
\text { Forum (Business } \\
\text { Competitiveness } \\
\text { Index) }\end{array}$} & 2013 & $110 / 144$ & \multirow{5}{*}{$\begin{array}{l}\text { Composite index based on } 12 \text { pillars indicators } \\
\text { measuring conditions, competitiveness: } \\
\text { Institutions, Infrastructure, Macroeconomic } \\
\text { environment, Health and primary education, } \\
\text { Higher education and training, Goods market } \\
\text { efficiency, Labor market efficiency, Financial } \\
\text { market development, Technological readiness, } \\
\text { Market size, Business sophistication Innovation }\end{array}$} \\
\hline & 2014 & $100 / 148$ & \\
\hline & 2015 & $79 / 144$ & \\
\hline & 2016 & $87 / 140$ & \\
\hline & 2017 & $87 / 137$ & \\
\hline $\begin{array}{l}\text { World Investment } \\
\text { Report (FDI } \\
\text { Potential Index) }\end{array}$ & 2017 & $101 / 140$ & $\begin{array}{l}\text { Composite index based on a dozen indicators of } \\
\text { attractiveness of the country for foreign } \\
\text { investment flows }\end{array}$ \\
\hline $\begin{array}{l}\text { WTTC (WORLD } \\
\text { Travel \& Tourism } \\
\text { competitiveness } \\
\text { Report 2017) }\end{array}$ & 2017 & $118 / 136$ & $\begin{array}{l}\text { The set of factors and policies that enable the } \\
\text { sustainable development of tourism }\end{array}$ \\
\hline \multirow[t]{2}{*}{$\begin{array}{l}\text { ONU, (Index of } \\
\text { human } \\
\text { development) }\end{array}$} & 2016 & $\begin{array}{c}83 / 188 \\
\text { Rank } 3 \text { in Africa } \\
\text { and rank } 6 \text { in } \\
\text { the Arab world }\end{array}$ & \multirow[t]{2}{*}{$\begin{array}{l}\text { Composite index based on a few health, } \\
\text { education and per capita income indicators }\end{array}$} \\
\hline & 2017 & $85 / 189$ & \\
\hline
\end{tabular}

According to the Table 4, between two rankings (2014 and 2015) Algeria was in $21^{\text {st }}$ position in the world ranking, which is indeed positive. Although considerable effort is 
still required to improve the competitiveness of the Algerian economy. The World Economic Forum's 2015 annual report, focused in the competitiveness of African economies, Reported an improment of the competitiveness in the northern countries including Algeria. It is based on criteria such as GDP (Gross Domestic Product), the global value chain, the evolution of infrastructure and the education system that Algeria has been able to gain rank. The positive evolution of its ranking is therefore linked to these specific criteria. The economies of North Africa are noted according to the evolution of three major sectors that determine the score of each country in the region.

The first is the basic needs sector, which includes institutions, infrastructure, the macroeconomic environment, health and education. Secondly, performance concerns the quality of education, the efficiency and size of the market, and the finance and technology development. The third sector is innovation.This is how countries earn points in some of these sectors and lose in others. Regarding tourism competitiveness it was first developed in 2001 by WTTC (WORLD Travel \& Tourism competitiveness) a competitiveness index of tourism in collaboration with the University of Nottingham. It is based on eight synthetic indicators that make it possible to assess the performance of each country relative to others. Price competitiveness is one of the major components. Built from an indicator based on hotel prices and purchasing power parity, the price competitiveness indicator ranges from $o$ (the least competitive country) to 100 (the most competitive country). At the global level, there is a correlation between income level and price competitiveness: countries with high income levels are the least competitive. But this correlation weakens a lot when we consider the only emerging countries: the lowest income countries are not the most competitive and the most competitive countries go from Ethiopia to South Africa through Brazil. Algeria is in this category among the most competitive destinations, tied with Thailand. Among the Mediterranean countries, it appears as the most competitive country with a score of 91 ahead of Turkey, Egypt, Jordan and Morocco (Chaponnière \& Lautier, 2005, p.18).

However, performance under this criterion does not systematically imply higher incomes for the country concerned. The price competitiveness of a destination depends on endogenous factors (costs, productivity) and on a set of indicators the notional actors miss. It depends in particular on-air fares, which are related to the degree of liberalization of the sector and mainly related to travel agencies who play a significant role in the profitability of the sector, because of their influence on lowering the prices on bulk reservations. In a context of hotel overcapacity, their commercial power often allows them to impose on their own price conditions that barely cover their fixed costs. In the (World Travel \& Tourism competitiveness Report 2003) approach, tourism competitiveness is based on other, more qualitative elements (Figure 6):

- The index of openness covers several indicators (visa process, ease of currency exchange, tax policies);

- the "human tourism" index is the average of the tourism participation index (ratio of the number of tourists to the population) and an indicator measuring its economic impact;

- the infrastructure index is based on data on roads, sanitation and access to water

- Environmental Index aggregates data on population density, CO2 emissions and implementation of international environmental agreements;

- the technology index is mainly based on telecommunication diffusion rates;

- the Human Resources Index is based on the UNDP Education Index;

- $\quad$ social development index aggregates "social" indicators and media and Internet dissemination indicators.

The World Economic Forum (WEF) published its second report (World Travel \& Tourism competitiveness Report 2008, p.14) based on the competitiveness indicator of 
130 countries in terms of travel and tourism. This report assessed the determinants of the competitiveness of the travel and tourism sector by identifying the ways to improve its competitiveness. It also identified the main obstacles to tourism competitiveness in each country. According to this report, Algeria was ranked 102nd behind most countries considered in index. The WEF has established an index to assess the competitiveness of each country in the travel and tourism. The Travel \& Tourism Competitiveness Index (TTCI) (World Travel \& Tourism competitiveness Report 2017).

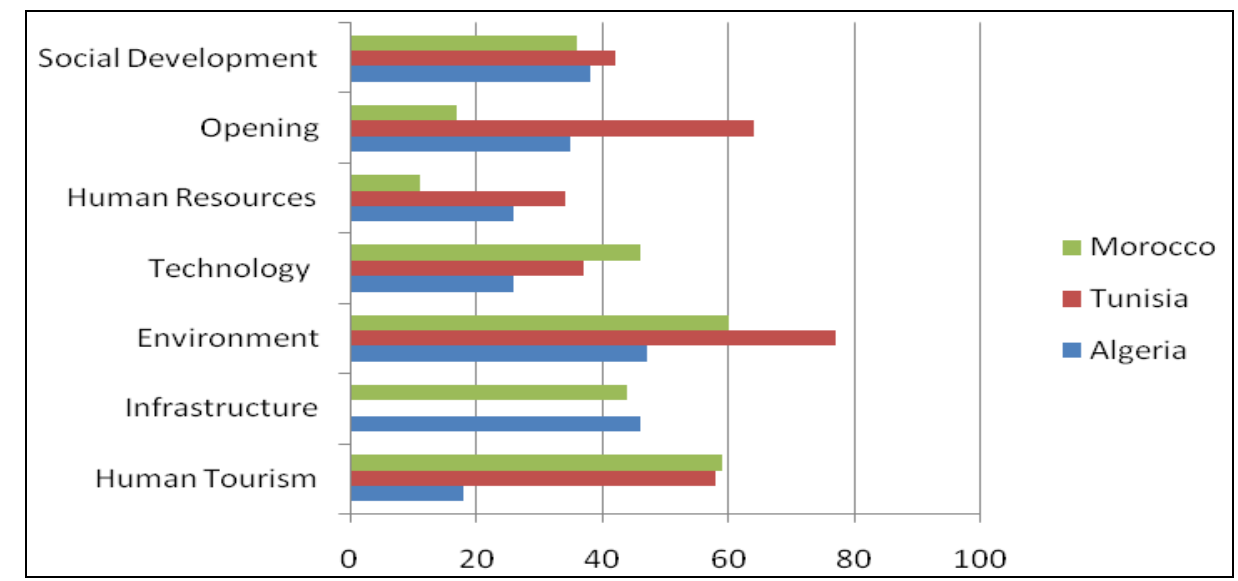

Figure 6. Ranking of Algeria in relation to the country of the Maghreb by the indicators of WTTC (2003) (Data Source: World Travel \& Tourism competitiveness Report 2003)

It measures, in a synthetic way, the factors and determinants of the competitiveness of the sector in 130 countries, as well as the effectiveness of policies to maintain and increase the attractiveness of this sector at the international level. The reputation and the improvement of the tourist competitiveness of a country evolved, indeed, according to multiple political, regulatory, human and environmental actions. These actions considered as part of the overall index consisted of 14 pillars structured in three broad categories:

(a) the regulatory framework for travel and tourism: includes factors essential to the stage of development of travel and tourism, such as the regulatory environment, the level of safety and the degree of priority accorded by the government to this sector and levels achieved in terms of health and hygiene;

(b) The business environment in the sector, the quality of air and land transport infrastructure, as well as information and communication technology infrastructure and price competitiveness in the industry;

\section{(c) The quality of human, cultural and natural resources.}

Each pillar is composed of several variables (71 in total) and described a stage of development of the tourism sector of the country The TTCI (The Travel \& Tourism Competitiveness Index) was elaborated in collaboration with a certain number of associated organizations and partners as well as heads of companies in the field of travel and tourism. It is based both on quantitative data from public sources, international institutions, travel and tourism experts, and on the results of surveys and opinion polls conducted by business leaders and investors in the field of travel and tourism.

\section{Methodological deficiencies}

Some limitations that impacted the relevance of the TTCI index. We noted:

- The subjective nature of the questionnaires: $40 \%$ of the variables used come from surveys 
Public opinion (qualitative variables). At this level, the risk of having wrong answers reflecting perceptions is not negligible;

- The incomplete information of the respondents, which risks generating a systematic bias of Responses and therefore bias aggregation of the overall index;

- The cultural bias of international opinion surveys because of the cultural differences to the interviewed persons (they may show patriotism in favor or against a given country, possibly under the influence of objectives of the body conducting the survey);

- Problems of international comparability of responses: the formulation of questions orients the answer to favorize the coutries against authors wich compromises the overall accuracy of the ranking.

The ranking of Algeria at 118 ranks is interesting in the comparisons it allows to make with the various countries selected, numbering 136 in 2017, and especially in the indicators and sub-indicators that it covers, and the comparison scores achieved at these levels with those of other countries in the same perimeters. The report, which analyzes the performance of 136 economies through the Travel and Tourism Competitiveness Index (TTCI), provides a unique overview of each country's strengths and development areas to improve industry competitiveness. It allows for cross-country comparisons, for assessing progress in country policy and for making investment decisions related to business and industry development.

First compiled in 2007, the Travel and Tourism Competitiveness Index (TTCI) measures "all factors and policies that enable the sustainable development of the Travel \& Tourism sector, which, in turn, contributes to development and competitiveness of a country ". The index was developed as part of the World Economic Forum's Industrial Program for Aviation, Travel and Tourism and in close collaboration with data partners Bloom Consulting, Deloitte-STR Global, the International Air Transport Association (IATA), the International Union for the Conservation of Nature the $\mathrm{T} \& \mathrm{~T}$ competitiveness index measures four main factors of competitiveness.The following fourteen factors are organized under four categories covering the general settings needed for the the Travel and Tourism Competitiveness Index:

Business environment

- $\quad$ Safety and security

- Health and hygiene

- Human Resources and the Labor Market

- ICT preparation

T \& T's Activation Policies and Conditions sub-domain, which captures specific policies or strategic aspects that have a more direct impact on the T \& T industry:

- Focus on travel and tourism

- International opening

- $\quad$ Competitiveness of prices

- Environmental sustainability

Sub-index of Infrastructure, which captures the availability and quality of the physical infrastructure of each economy:

- Air transport infrastructure

- Terrestrial and port infrastructure

- Tourism service infrastructure

The sub-domain of natural and cultural resources, which captures the main "reasons to travel":

- $\quad$ Natural resources

- Cultural Resources and Business Travel

This flagship report is one of the most effective and instructive in the world, considering the quality of the teams that have been responsible for its elaboration, the 
tools and indicators it uses to measure the performance of countries in the fields of the research it retains, its methodology, as well as its usefulness for the managers and decision-makers in charge of the national and sectoral policies it concerns.

\section{CONCLUSION}

The attractiveness of the territory does not therefore constitute an "absolute" concept, capable of being the subject of a single measure, nor, a fortiori, of a concept fixed in time. It can only be defined in a relative way, as the capacity of the territory considered to respond more effectively than its competitors to the demand of tourists.

The different approaches to attractiveness have been presented in this article lead each has specific implications for territorial development policies:

We have tested through this study of the factors that affect competitiveness and we have found that its last can change quickly, which makes the task even more complex.

The Algerian territory responds to all the criteria of tourist attractiveness, but this manager still occupies the last ranks in terms of competitiveness this is due mainly to the economic development model adopted by Algeria which does not allow the latter to increase its returned. Algeria, which has experienced a security crisis, has seen a few years ago thanks to a legal text of reconciliation (www.interieur.gov.dz/index.php/en /dossiers/168-the-charter-for-the-peace-and-national-reconciliation.html) a changeover to peace, in 2018 Algeria is no longer in the Top-10 countries at high risk of terrorist attack Indeed, this is what emerged from the last report of the Global Terrorism Index (GTI) (Global Terrorism Index 2018, p.9) the country has combined political, economic, social, cultural and religious measures involving all institutions and inhabitants.

Some proposals are vital for a country like Algeria:

- $\quad$ Capitalize on competitive attributes

- Affirm a positive and rewarding image of Algeria for all clienteles (national and Foreign)

- $\quad$ Boost the country's overall attractiveness

- $\quad$ Restore trust

- $\quad$ Renew the image of Algeria by building on its main competitive advantage over the perception of Morocco and Tunisia destinations: the Sahara at the gates of Black Africa

\section{REFERENCES}

Chaponnière, J.R., \& Lautier, M. (2005). Tunisia and the Euro-Mediterranean tourism market. Report of the french development agency, Paris, p.40.

Courlet, C., \& Pecqueur, B. (2013). L'économie territoriale. Presse Universitaire de Grenoble, France.

Cracolici, M. F., \& Nijkamp, P. (2008). The attractiveness and competitiveness of tourist destinations: A study of Southern Italian regions. Tourism Management, no. 30, p. 336-344, Elsevier, USA.

Deng, J., King, B., \& Bauer, T. (2002). Evaluating natural attractions for tourism. Annals of Tourism Research, vol. 29, no. 2, p. 422-438, Elsevier, USA.

Devereux, M.P., \& Griffith, R. (1998). Taxes and the location of production: evidence from a panel of US multinationals. Journal of Public Economics, ${ }^{\circ} .68$, p $335-367$, Elsevier, USA.

Dupeyras, A., \& MacCallum, N. (2013). Indicators for Measuring Competitiveness in Tourism: A Guidance Document. OECD Publishing, Paris, p15.

Enright, M. J., \& Newton, J. (2004). Tourism destination competitiveness: a quantitative approach. Tourism Management, no. 25, p.777-788, Elsevier, USA.

Escadafal, A. (2007). Attractivité des destinations touristiques: quelles stratégies d'organisation territoriale en France? Téoros, vol.26, No.2. p. 27-32, UQAM, CANADA.

Galarneau, D.O. (2015). The attractiveness of the tourist territory. Doctoral thesis, University of Laval, p.137.

Gallarza, M.G., Gil, S. I., \& Calderon, G.H. (2002). Destination image, Towards a conceptual Framework. Annals of Tourism Research, vol.29, no. 1, pp. 56-78, Elsevier, USA.

Giotart, J. Balfet, M., \& Leroux, E. (2012). Management du tourisme. Pearson édition, France.

Hatem, F. (2004). Attractivité : de quoi parlons-nous ? Pouvoirs Locaux, vol.2, No.61. p. 34, IGTD, Paris.

Khadaroo, J., \& Seetahah, B. (2008). The role of transport infrastructure in international tourism development: A gravity model. Tourism Management, no. 29, p. 831-840, Elsevier, USA. 
Kim, H.B. (1998). Perceived attractiveness of Korean destinations. Annals of Tourism Research, vol.25, no.2, p.340-361, Elsevier, USA.

Kim, J.H. (2010). Determining the factors affecting the memorable nature of travel experiences. Journal of Travel and Tourism Marketing, vol. 27, p. 780-796, Taylor \& Fancis, UK.

Kusen, E. (2010). A system of tourism attractions. European journal of Tourism, vol. 58, no. 4, p. 409- 425, ProQuest, Bulgaria.

Leiper, N. (1990). Tourist attraction system. Annals of Tourism Research, vol.17, p. 367-384, Elsevier, USA.

Lew, A. (1987). A framework of tourist attraction research. Annals of Tourism Research, vol.14, p. 553-575, Elsevier, USA.

Lepage, L.B., \& Gollain, V. (2015). Attractivité et compétitivité des territoires théories et pratiques. CNER, Paris.

Nolan, M., \& Nolan, S. (1992). Religious sites as tourism attractions in Europe. Annals of Tourism Research, vol. 19 , p. 68-78, Elsevier, USA.

Van der Ark, L.A., \& Richards, G. (2006). Attractiveness of cultural activities in European cities: A latent class approach. Tourism Management, no. 27. p. 1408-1413, Elsevier, USA.

Ritchie, J.R., \& Zins, M. (1978). Culture as determinant of the attractiveness of tourism region. Annals of Tourism Research, April/June. p. 252-267, Elsevier, USA.

Smith, S.L.J. (1987). Regional analysis of tourism resources. Annals of Tourism Research, vol. 14, pp. 254-273 Elsevier, USA.

Smith, V.L. (1980). Anthropology and tourism: A science-industry evaluation. Annals of Tourism Research, vol. 7, pp. 13-33, Elsevier, USA.

Viceriat, P., Origet Du Cluzeau, C., Levy, M., Doublet, M., \& Gros, D. (2007). Tourism attractiveness of major French cities and structuring effects on regional tourism. Report of the Tourism direction, Paris, p57.

Wang, C.Y., \& Hsu, M.K. (2010). The relationships of destination image, satisfaction and behavioral intentions: an integrated model. Journal of Travel and Tourism Marketing, vol.27, p.829-843, Taylor \& Fancis, UK.

*** (2001). World Economic Forum, World Travel and Tourism Council, How does Travel and Tourism compare to other sectors? Summary of Findings, Retrieved from http://www.wttc.org/site_media/uploads/downloads/WTTC_Business_Travel_2011.pdf

*** (2003). World Economic Forum, World Travel \& Tourism competitiveness Report.

*** (2008). World Economic Forum, The travel and tourism competitiveness report 20o8. Retrieved from http://www3.weforum. org/docs/WEF_TravelTourismCompetitiveness_Report_2008.pdf.

*** (2009). World Economic Forum, The travel and tourism competitiveness report 2009: Managing in a time of turbulence. Retrieved from http://www.weforum.org/reports/travel -tourism -competitiveness- -report

*** (2011). World Economic Forum, The travel and tourism competitiveness report 2011: Beyond the downturn. Geneva: World Economic Forum. Retrieved from http://www.weforum.org/reports/travel -tourism competitiveness -report -2011.

*** (2012). World Economic Forum, The Global Competitiveness Report, Retrieved from http://www3.weforum.org/docs/WEF_GlobalCompetitivenessReport_2012-13.pdf.

*** (2013). World Economic Forum, The travel and tourism competitiveness report 2013: Reducing barriers to economic growth and job creation. Geneva: World Economic Forum. Retrieved from http://www3.weforum.org/docs/WEF_TT_Competitiveness_Report_2013.pdf

*** (2014). World Economic Forum, Travel \&Tourism Competitiveness: A Study of World's Top Economic Competitive Countries, procedia Economics and Finance, Volume 15, Pages 1273-1280

*** (2017). World Economic Forum, The Global Competitiveness Report, p.11.

*** (2010). World Tourism Organisation, Tourism Towards 2030/Global Overview http://pub.unwto.org /WebRoot/Store/Shops/Infoshop/4E98/o7B6/A1D8/382D/5B35/CoA8/0164/3066/111014_TT_2030 global_overview_excerpt.pdf

*** (2012). World Tourism organization, Faits saillants du tourisme, Retrieved from:

http://dtxtq4w6oxqpw.cloudfront.net/sites/all/files/pdf/unwto_highlights12_fr_hr.pdf, p15.

*** (2018). World Tourism Organization, Tourism Highlights, p.18

*** (2017). United Nations Conference On Trade And Development, World Investment Report, p.44.

*** (2008). Ministry of Tourism, Algeria, Book 1: Tourist Priority Projects, SDAT 2025, p.6.

*** (2017). Ministry of Tourism, Algeria, tourism and craft dashboard, p.5.

*** (2017). Ministry of Tourism, Algeria, report on the Algerian tourism indicators 1999-201, p.9

*** (2017). Ministry of commerce, Algeria, National Trade Registry Center.

*** (2017). Ministry of Culture, Algeria, Statistics, p.167.

*** (2018). Global Terrorism Index 2018, p9.http// eliefweb.int/report/world/global-terrorism-index-2018 www.whc.unesco.org/fr/etatsparties/dz.

www.interieur.gov.dz/index.php/fr/dossiers/168-la-charte-pour-la-paix-et-la-reconciliation-nationale.html accessed 15.12.2018.

Submitted:

07.11.2018
Revised:

06.02.2019
Accepted and published online o8.02.2019 